İş ve İnsan Dergisi I The Journal of Human and Work

Y1l | Year: Nisan | April 2017

Cilt-Sayı | Volume-Issue: 4 (1)

ss I pp: $61-71$

doi: 10.18394/iid.284318

e-ISSN 2148-967X

http://dergipark.gov.tr/iid/

Araștırma Makalesi

\title{
İç Grup Her Zaman İyi Asker Midir? Dönüșümcü Liderlik - Örgütsel Vatandaşık Davranışı İlişkisinde Lider Üye Etkileşiminin Rolü
}

\author{
Is In-Group Always the Good Soldier? The Role of Leader Member Exchange on the \\ Relationship between Transformational Leadership and Organizational Citizenship \\ Behaviour
}

\author{
Özgür Ayhan*, a , Faruk Şahin ${ }^{\mathrm{b}}$
}

\section{MAKALE BİLGİSİ}

Anahtar Kelimeler:

Dönüsümcü liderlik,Lider

üye etkileşimi, Örgütsel

vatandaşlık davranışı

\section{Tarihler:}

Geliş 05 Ocak 2017

Kabul 03 Mart 2017
ÖZ

Bu çalışmanın amacı; dönüşümcü liderliğin örgütsel vatandaşlık davranışı üzerindeki etkisini incelemek ve bu etkide lider-üye etkileşiminin aracılık rolü olup olmadığını test etmektir. Araştırmanın hipotezleri, Ankara'da faaliyette bulunan iki farklı kamu kurumundan 50 lider ve bunların takipçisi 235 işgörenden elde edilen çok kaynaklı veriler üzerinden, yapısal eşitlik modellemesi ile test edilmiştir. Araştırma sonucunda, dönüşümcü liderliğin örgütsel vatandaşlık davranışı üzerinde önemli etkiye sahip olduğu ortaya konulmuştur. Dönüşümcü liderliğin örgütsel vatandaşlı üzerindeki etkisinin örgüte karşı sergilenen vatandaşlık davranışlarını, bireye karșı sergilenen vatandaşlık davranışlarından daha güçlü șekilde etkilediği tespit edilmiştir. Bununla birlikte söz konusu ilişkide lider üye etkileşimin aracr etkiye sahip olduğu ortaya konulmuştur. Buna göre dönüșümcü liderlik öncelikle takipçiler ile kaliteli etkileşimi etkilemekte, kaliteli etkileşimin neticesi olarak da takipçiler vatandaşlık davranışı sergilemektedir. Dönüşümcü liderlerin takipçilerinin vatandaşlık davranışı sergilemelerinin yolunun kendilerini iç grupta hissetmelerine bağll olduğu görülmüş̧ür.

\section{ARTICLE INFO}

\section{Keywords:}

Transformational leadership, Leader member exchange, Organizational citizenship behaviour

\section{Article history:}

Received 05 January 2017

Accepted 03 March 2017

\begin{abstract}
A B S T R A C T
The present study aimed to investigate the effects of transformational leadership on organizational citizenship behavior and mediating effect of leader member exchange on that relationship. Research hypotheses were tested with a sample of 50 leaders and 235 of their followers in two different public sector institutions from Ankara using structural equation model. As a result of this study, it was found that transformational leadership has significant effect on organizational citizenship behavior. It is found that transformational leadership behavior had more powerful impact on organizational citizenship behavior toward organization than toward individual. Moreover, leader member exchange had mediating role on transformational leadership-organizational citizenship behavior. The results indicate that transformational leadership affects exchange quality between leader and follower, then followers' citizenship behavior is affected by exchange quality. In order to promote citizenship behavior, followers feel themselves as an in-group member of their transformational leader.
\end{abstract}

\footnotetext{
*, a Iletişim Kurulacak Yazar, Yıldırım Beyazıt Üniversitesi, Sosyal Bilimler Enstitüsü, Ankara,Türkiye.ayhanazzzgur@gmail.com

${ }^{b}$ Muğla Sıtkı Koçman Üniversitesi, Fethiye Isşletme Fakültesi, Fethiye, Muğla, Türkiye.fsahin@mu.edu.tr
} 


\section{GíRiş}

Burns (1978) tarafindan ortaya atıldığ 1 ilk günden bu güne liderlik yazınında en çok çalışılan konu olan dönüşümcü liderlik, ortak vizyon ve paylaşılan değerler vurgusu ile örgütsel çıkarların şahsi çıkarların önüne geçirilmesinin sağlanması süreci olarak tanımlanmaktadır (Bass, 1985). Batı bağlamında ortaya çıkan dönüşümcü liderlik ve etkilerinin bu kadar çok çalışılmasında (örn., Bass \& Avolio, 1993; Casimir, Waldman, Bartman \& Yang, 2006; Kouzes \& Posner, 2002; Wang, Oh, Courtright \& Colbert, 2011) dönüşümcü liderliğin ve etkilerinin her kültür ve bağlamda geçerli olduğu iddiası yatmaktadır (Bass, 1997). Öte yandan liderlik yazını incelendiğinde dönüşümcü liderliğin etkileri noktasında tam bir fikir birliği olduğunu söylemek mümkün görünmemektedir. Casimir ve arkadaşları (2006), doğu ve batı bağlamından iki farklı örneklem üzerine yaptıkları çalışmada dönüşümcü liderliğin örgütsel vatandaşlık davranışı üzerindeki etkisinin batı bağlamında istatiksel olarak anlamlı olduğunu, ancak doğu bağlamında etkinin anlamsız olduğunu raporlamışlardır. Dolayısıyla dönüşümcü liderlik ve örgütsel vatandaşlık davranışı gibi iş çıktıları arasındaki ilişkinin farklı bağlamlarda test edilmesine ihtiyaç vardir.

Ayrıca dönüşümcü liderlik ve örgütsel vatandaşlık davranışı ilişkisinde ağırlıklı olarak tutumlara ve davranışlara odaklanıldığı ve ast ve üst arasındaki ilişkinin kalitesinin göz ardı edildiği görülmektedir. Dolayısıyla lider ve takipçileri arasındaki ilişkinin kalitesinin dönüşümcü liderlik-örgütsel vatandaşlık davranışı ilişkisindeki rolünün ortaya konulması önem arz etmektedir. Buradan hareketle bu çalışmanın amacı, dönüşümcü liderliğin örgütsel vatandaşlık davranışı üzerindeki etkisinin doğu bağlamında ve Globe çalışmasında Türk-Arap kümesinde yer alan Türkiye bağlamında araştırılmasıdır. Ayrıca söz konusu ilişkide lider üye etkileşimin aracılık rolünün olup olmadığının ortaya konulması amaçlanmıştır.

$\mathrm{Bu}$ çalışmanın alan yazına üç temel katkısının olacağ1 düşünülmektedir. Birincisi, dinamik iç grupların önemli yer tuttuğu Türk kültüründe (Sargut, 2010) dönüşümcü liderliğin ve lider üye etkileşiminin örgütsel vatandaşlık davranışı üzerinde etkilerinin ortaya konularak değişkenler arasındaki ilişkilerin daha anlaşılır kılınmasının alan yazına mütevazı bir katkı olacağı düşünülmektedir. Ayrıca daha önce yapılmış çalışmalar incelendiğinde, değişkenler arasındaki ilişkiyi inceleyen çalışmalarda lider üye etkileşiminin aracılık etkisinin göz ardı edildiği görülmektedir. $\mathrm{Bu}$ çalışmayla birlikte lider üye etkileşiminin değişkenler arasındaki ilişkide aracı etkiye sahip olup olmadığı ortaya konulmuştur. Üçüncüsü, dönüşümcü liderlik - örgütsel vatandaşlık davranış1 üzerinde etkili olan aracı değişkenlere dair yapılan çalışmalarda daha çok tutum ve davranışlara odaklanılırken, ast ve üst gibi örgütsel aktör arasındaki ilişkiye odaklanılması çalışmaya değer katmaktadır. Dördüncüsü, alan yazında yapılmış çalışmalarda önemli bir kısıt olarak zikredilen ortak yöntem varyansı ve sosyal beğenilirlik etkilerinin önüne geçmek maksadiyla bu çalışmada çok kaynaktan veri toplanarak liderlerin dönüşümcü liderlik davranışı astlar tarafından, astların sergiledikleri örgütsel vatandaşlık davranışı ise liderler tarafından değerlendirilmiştir.

\section{KAVRAMSAL ÇERÇEVE}

\subsection{Dönüşümcü Liderlik}

Dönüşümcü liderlik (DL) takipçilerin davranışlarına önemli değişiklikler yaprak, onları örgütün amaçları doğrultusunda harekete geçirme süreci olarak tanımlanmaktadır (Yukl, 1999). Alan yazında ilk olarak Burns (1978) tarafindan kullanılan DL, takipçilerinin potansiyelini geliştirmek için onlara ilham olmakta ve onları yönlendirmektedir (Bass \& Avolio, 1990). Bass (1985) dönüşümcü liderleri görevin önemine ve örgütün değerlerine vurgu yapan, örgütsel çıkarların şahsi çıkarların önüne koyulmasını sağlayan ve takipçilerinin her birine bir birey olarak yaklaşarak onlara değer veren liderler olarak tanımlamaktadır. DL, astların dönüşümünün sağlandığı bir süreç olarak da tanımlanmaktadır. $\mathrm{Bu}$ sürecin sonunda takipçilerin beklenenin ötesinde performans sergilemeleri ve olumlu iş tutum ve davranışları geliştirmeleri ve kişisel çıkarlarını, örgütsel çıkarların gerisinde konumlandırmaları beklenmektedir (Bass \& Avolio, 1990). Robbins ve Coulter (2007) dönüşümcü lideri, takipçilerine ilham veren ve beklentilerin ötesine taşıyan kişi olarak tanımlamaktadır.

DL, karizma ve ideal etki, entelektüel teşvik, ilham verici motivasyon ve bireysel ilgi boyutlarından oluşmaktadır (Bass \& Avolio, 1990). Karizma ve ideal etki, dönüşümcü liderin hayranlık uyandıran bir karizmaya sahip olmasını ifade eder. Ayrıca ideal etki ortak vizyon ve ortak amaca işaret etmektedir (Bass \& Avolio, 1995). Karizma ve ideal etki boyutu dönüşümcü liderin karizmasını kullanarak takipçilerini ortak misyon ve vizyon etrafinda toplamayı gerektirmektedir (Bass \& Avolio, 1990). Bununla birlikte karizma ve ideal etkininin bir gerekliliği olarak dönüşümcü liderler kendi çıkarlarını astlarının çıkarlarının gerisinde tutarlar (Bass \& Avolio, 2003). Entelektüel teşvik 
boyutu, dönüșümcü liderlerin yeni çözüm yolarına açıklığını ifade etmektedir (Bass \& Avolio, 1990). Dönüşümcü liderler, problemler karşısında takipçilerinin yeni çözüm yolları denemelerini teşvik ederek onların gelişmelerini sağlarlar (Bass \& Riggio, 2006). İlham verici motivasyon boyutu ise dönüşümcü liderin takipçileri için çizdiği yolu ifade etmektedir (Bass \& Avolio, 1990). Dönüşümcü liderler, takipçilerin kişisel beklentileri ile örgütsel beklentileri uyumlu hale getirerek, takipçileri ortak amaç doğrultusunda hareket ettirirler (Hinkin \& Tracey, 1999). Son olarak bireysel ilgi boyutu, dönüşümcü liderlerin her bir takipçisine birey olarak yaklaşmasını ve onların ihtiyaç ve beklentilerine karşı hassas oluşunu ifade etmektedir (Bass \& Avolio, 1990). DL'de takipçilerin bireysel farklılıkları bir problem olarak değil bir değer olarak görülmektedir (Bass \& Riggio, 2006). Dönüşümcü liderin takipçilerini desteklemesi ve onları geliştirmeye çalışması bireysel ilgi boyutunda değerlendirilmektedir (Yukl, 1999).

DL ve iş çıktılarına yönelik yapılmış olan görgül çalışmalarda DL'nin düşük iş devir hızı, yüksek üretkenlik, iş tatmini, lider üye etkileşimi, ekstra rol davranışı ve takipçilerin refahı gibi değişkenler üzerinde etkili olduğu ortaya konulmuştur. (Deluga, 1992; Keller, 1992; Piccolo \& Colquitt, 2006).

\subsection{Lider Üye Etkileşimi}

DL'nin yordadığı düşünülen en önemli değişkenlerden biri olan lider üye etkileşimi (LÜE) liderlerin her bir takipçisiyle farklı ilişkilere sahip olduğunu ileri sürmektedir. (Harris, Kacmar \& Carlson, 2006). LÜE, kuramsal olarak rol yapma (Graen, 1976) ve ikili mübadele (Graen \& UhlBien, 1995) teorilerine dayanmaktadır. Graen, Dansereau ve Minami (1972) liderin etkileşimde bulunduğu tüm grup üyeleri ile aynı kalitede etkileşim kurmadığını belirtmektedir. Bazı takipçilerin lideri ile olan ilişkisi daha sıcak iken bazılarının daha resmidir. Lider ile yakın ilişki içerisinde bulunan takipçiler iç grup olarak sınıflandırılırken, lider ile ilişkisi görece zayıf olan takipçiler dış grup olarak sınıflandırılmaktadır. Yüksek kaliteli etkileşimin bir sonucu olarak iç grupta yer alan takipçilerin resmi ve gayri resmi ödüllere, kaliteli iletişime, üste kolay erişim gibi avantajlara daha kolay ulaşılacağı ileri sürülmektedir (Dienesch \& Liden, 1986). İç gruptakilerin elde ettiği bu avantajların aksine diş grupta yer alan takipçiler herhangi bir avantajdan faydalanamazlar. Diş grup gruptaki takipçiler ile lider arasındaki ilişki iş tanımında yer alan resmi tanım çerçevesinde şekillenmektedir (Liden \& Graen, 1980). Lider ve iç gruptaki takipçiler arasındaki ilişki ikili mübadele teorisi etrafında şekillenirken, dış gruptaki takipçiler ile olan etkileşim daha çok rol yapma teorisi temelinde şekillenmektedir.

Alan yazında LÜE'nin iş çıktıları üzerindeki etkisine dair çalışmalar bulunmaktadır. Gerstner \& Day (1997) alan yazında yapılmış olan çalışmaları toplayarak yaptıkları meta analiz de LÜE'nin olumlu iş çıktıları ile olan ilişkisinini ortaya koymuştur. Lider ve takipçi arasındaki yüksek kaliteli etkileșimin iş performansı (Özutku, Ağca \& Cevrioğlu, 2008) ve iş tatmini (Graen. Novak \& Sommerkamp, 1982) gibi çıktılar üzerinde etkili olması beklenmektedir.

\section{3. Örgütsel Vatandaşlık Davranışı}

DL'nin en önemli çıktılarından olan ve işgörenlerin sergiledikleri ekstra çabaları ifade eden Örgütsel Vatandaşlık Davranışı (ÖVD) kuramsal temellerini Barnard (1968) ve Katz'ın (1964) çalışmalarından almaktadır. İlk olarak Organ (1988) tarafindan kavramsallaştırılan ÖVD örgütün yer aldığ 1 sosyal ve psikolojik çevreyi destekleyen davranışlar olarak da tanımlanmaktadır (Organ, 1988). ÖVD, işgören ve işveren arasında yapılan sözleşmede yer alamayan, işgörenin tamamıyla gönüllülüğüne bağlı ortaya koyduğu davranışları kapsamaktadır (Gürbüz, 2007). Ortaya atıldığı ilk günden bugüne alan yazında en çok çalışılan örgütsel çıktıların başında gelen ÖVD'nin alt boyutlarına dair pek çok sınıflandırma mevcuttur. Araştırmacılar arasında yaygın şekilde kabul gören ve diğer sınıflandırma çalışmalarına dayanak teşkil eden Organ'ın (1988) sınıflandırmasına göre ÖVD beş boyuttan oluşmaktadır. Bunlar; diğerkâmlık, nezaket, sivil erdem, vicdanlılık ve centilmenliktir. Organ (1988) bu sınıflandırmayı yaparken sergilenen davranışa odaklanmıştır. Williams ve Anderson (1991) ise davranışın yönüne ve davranıştan etkilenenlere göre bir sınıflandırma yaprak ÖVD’yi iki alt boyuta ayırmıştır. Yazarlar bireye yönelik sergilenen davranışları örgütsel vatandaşlık davranış1-birey (ÖVD-birey), örgüte yönelik sergilenen davranışları ise örgütsel vatandaşlık davranışı-örgüt (ÖVDörgüt) olarak adlandırmışlardır (Williams \& Anderson, 1991). ÖVD-birey Organ (1988)'ın beşli sınıflandırmasında yer alan diğerkâmlık ve nezaket boyutundan beslenirken, ÖVD-örgüt sivil erdem vicdanlılık ve centilmenlik boyutlarından beslenmektedir.

\subsection{Araștırmanın Modeli ve Hipotezler}

DL ile ÖVD arasındaki ilişkinin anlamlandırılmasında sosyal mübadele kuramının (Blau, 1964) açıklayıcı olacağı düşünülmektedir. Dönüşümcü lider kendi çıkarlarını takipçilerinin 
çıkarlarının gerisinde konumlandıran ve onların kişisel ihtiyaç ve beklentilerine cevap veren liderler olarak tanımlanmaktadır (Bass \& Avolio, 1990). Sosyal mübadele kuramı gereği takipçilerin harcayacakları çabanın elde ettikleri kazanımlar ile orantılı olması gerekmektedir. Dolayısıyla liderin sergileyeceği bu tip davranışlar, takipçilerin beklentilerin ötesine geçmelerine ve daha çok gönüllü davranış sergilemelerine sonuç vermesi beklenmektedir. Şahsi ihtiyaçları karşısında duyarlı olunması ve gelişimi için çaba sarf edilmesi takipçilerin örgüt çıktıları doğrultusunda gönüllü çaba sarf etmesini gerektirmektedir. Kendileri için ekstra davranışlar sergilenen takipçilerin ÖVD sergilemeleri beklenmektedir.

Öte yandan alan yazında yapılmış olan çalışmalarda da DL'nin ÖVD üzerindeki etkisi ortaya konulmuştur (örn., Bass \& Avolio, 1993; Casimir vd., 2006; Kouzes \& Posner, 2002; Wang vd., 2011). Ancak Casimir ve arkadaşları (2006) yaptıkları çalışmada DL'nin ÖVD üzerindeki etkisinin kültüre göre değişebileceğini ortaya koymuştur. Çin örneklemi üzerinde DL'nin ÖVD üzerindeki etkisinin istatiksel olarak anlamlı olmadığ1 görülmüş, ancak Avustralya örneklemi üzerinde yapılan çalışmada yazarlar olumlu etki raporlamışlardır (Casimir vd., 2006). Ayrıca DLÖVD ilişkisinin farklı bağlamlarda farklı düzeylerde çıkmış olması, söz konusu ilişkiye dair fikir birliğini engellemektedir. Alan yazında yapılmış olan çalışmalar, sosyal mübadele teorisi ve DL'nin tanımında yer alan takipçilerin dönüşerek örgütün amacı doğrultusunda hareket etmesi (Yukl, 1999) dikkate alınarak oluşturulan hipotez şu şekildedir;

Hipotez 1: Dönüşümcü liderlik astların bireye (H1a) ve örgüte yönelik (H1b) sergileyecekleri örgütsel vatandaşlık davranışını olumlu yönde etkiler.

Gerstner ve Day'in (1997) yapmış oldukları metaanaliz çalışmasında kaliteli LÜE ile olumlu iş çıktıları arasındaki ilişki ortaya koyulmuştur. Yüksek kalitede bir LÜE iş tatmini (Graen vd., 1982) ve performansı (Özutku vd., 2008) etkilerken, liderlik tarzından etkilenmektedir (Deluga, 1992). LÜE'nin en önemli öncüllerinden biri olarak DL görülmektedir (Deluga, 1992; Howell \& HallMerenda, 1999; Wang, Law, Hackett, Wang \& Chen, 2005). Deluga (1992) DL'nin LÜE için bir katalizör görevi gördüğünü iddia etmektedir. Bireysel ilgi boyutunun lider ve takipçi arasındaki ilişkinin kalitesini yükseltmesi beklenmektedir. Ancak Deluga (1992) yapmış olduğu çalışmada sadece karizma ve ideal etki boyutunun LÜE üzerinde anlamlı etkiye sahip olduğunu raporlamıştır. Çetin, Korkmaz ve Çakmakçı (2012) yaptıkları çalışmada DL ve LÜE arasında orta düzeyde anlamlı ilişki tespit etmişlerdir. Dolayısıyla DL'nin LÜE'yi etkilemesi beklemektedir.

LÜE teorisine göre iç grupta yer alan takipçilerin gönüllü davranışlar sergilemeleri olan bir durum iken, diş grupta yer alan takipçilerin ÖVD sergilemeleri beklenmemektedir. Dış grupta yer alan takipçiler ile lider arasındaki ilişkinin, iş tanımının ötesine geçmemesi sebebiyle, takipçilerin iş tanımın ötesine geçmesi beklenmemektedir. Ayrıca eşitlik teorisi (Adams, 1965) gereği, iç grupta yer alan takipçiler elde ettikleri kazanımlar ile iç gruptakilerin elde ettikleri kazanımları karşılaştırarak, söz konusu adaletsiz durum sebebiyle örgüte veya kişiye yönelik herhangi bir gönüllü çaba içerisinde bulunmayacaktır. Dolayısıyla öncelikle DL'nin kaliteli LÜE'ye sonuç vermesi, kaliteli LÜE'nin de ÖVD'yi yükseltmesi beklenmektedir. Howell ve Hall-Merenda (1999) yaptıkları çalışmada DL-ÖVD ilişsisine yönelik ortaya konulan regresyon modeline LÜE'yi de dahil ederek değişkenler arasındaki ilişkileri test etmişlerdir. Modele LÜE'nin dahil edilmesi ile DL'nin ÖVD üzerindeki etkisinin istatiksel olarak anlamsızlaştığı görülmüştür. Dolayısıyla LÜE'nin DL-ÖVD ilişkisinde aracı role sahip olabileceği düşünülmektedir. Alan yazında yapılmış olan çalışmalar ile LÜE teorisi ve eşitlik teorisi çerçevesinde oluşturulan araştırmanın ikinci hipotezi şu şekildedir;

Hipotez 2: Dönüşümcü liderlik - örgütsel vatandaşl1k davranış1- birey (H2a) ve örgütsel vatandaşlık davranışı-örgüt (H2b) ilişkisinde lider üye etkileşiminin aracılık rolü vardır.

\section{ARASTIRMANIN YÖNTEMI}

\section{1. Örneklem}

$\mathrm{Bu}$ çalışmanın araştırma evrenini kamu da çalışan liderler ve onların takipçileri oluşturmaktadır. Sargut 'un (2010) Türk kültüründe iç grupların etkili pek çok karar üzerinde etkili olduğu vurgusundan hareketle çalışma iki farklı kamu kuruluşunun Ankara birimlerinde çalışan 272 kişi çalışmaya dâhil edilmiştir. Kolayda örnekleme yöntemiyle seçilmiş 50 lider ve bunların takipçisi 272 kişilik bir örnekleme ölçeklerin yer aldığ 1 anketler ayrı ayrı dağıtılmıştır. Liderlerin tamamı ile görüşülerek anketlere $\% 100$ geri dönüş sağlanmıştır. Takipçilere uygulanan anketlerin 251 '’ geri toplanmıştır. Aşırı uç değerler ve eksik değerlendirmeler çıkarıldıktan sonra 235 kişiye ait kullanılabilir veriye ulaşılmıştır. Araştırmaya katılan katılımcılardan liderlerin yaş ortalaması 
36.43 yıl iken takipçilerin 33.80 yıldır. Liderlerin ortalama iş tecrübesi 15.2 yıl olarak hesaplanırken takipçilerin ortalama iş tecrübeleri 11.1 y1l olarak hesaplanmıştır. Lider ve takipçilerinin amir ve memur olarak birlikte çalışma sürelerinin ortalaması 1.82 yıldır. Ayrica liderlerin 25'i erkek iken araştırmaya katılan takipçilerin 190’1 erkektir. Araştırmaya katılan kadın katılımcıların sayısı ise liderler için 25, takipçiler için 45'tir.

\subsection{Veri Toplama Araçları}

Araștırmada veri toplama aracı olarak anket tekniği kullanılmıştır. Lider ve takipçileri için ayrı ayrı oluşturulan anketlerin birinci bölümünde demografik veriler yer alırken ikinci bölümde araştırmanın değișkenlerine yönelik ölçekler yer almaktadır. Bu kapsamda liderler, takipçilerinin ÖVD'lerini değerlendirirken, takipçiler ise liderin DL özelliğini ve LÜE'lerinin kalitesini değerlendirmişlerdir. Ölçeklerin güvenilirliğini hesaplamak için Cronbach $\alpha$ katsayıları hesaplanmıştır. Araştırmada kullanılan ölçeklerin güvenirlik değerlerinin tamamının alan yazında eşik değer olarak kabul edilen .70 üzerinde olduğu tespit edilmiştir. Ölçeklerin geçerliliğini test etmek için doğrulayıcı faktör analizi yapılmıştır. Tüm ölçeklerin geçerliliğine ayrı ayrı bakmak yerine ölçüm modeli test edilmiştir. Analiz neticesinde ölçüm modelinin uyum iyiliği değerlerinin alan yazında kabul edilen sınırlar içerisinde olduğu tespit edilmiştir $\left(\chi^{2}(344, \mathrm{~N}=235)=646.71 ; \chi^{2} / \mathrm{df}=1.879\right.$, $\mathrm{RMSEA}=.061, \mathrm{CFI}=.97)$.

\subsubsection{Küresel Dönüşümcü Liderlik Ölçeği}

Liderlerin sergiledikleri DL, Carless, Wearing ve Mann (2000) tarafindan geliştirilen Global Dönüştürücü Liderlik Ölçeği ile ölçülmüştür. Takipçiler tarafından değerlendirilen ölçek 7 maddeden oluşmaktadır. Küresel dönüşümcü liderlik ölçeği, DL'nin küresel ölçeği olarak kullanılmaktadır. Örnek madde "Benim liderim personeline birey gibi davranır, onların gelişimlerini destekler ve teşvik eder". Ölçek 5li likert formatında uygulanmıştır. Global Dönüştürücü Liderlik Ölçeğinin güvenilirlik katsayısının .87'in olduğu görülmüştür.

\subsubsection{Lider Üye Etkileşimi Ölçeği}

Lider ile takipçileri arasındaki ilişkinin kalitesi Graen ve Scandura'nın (1987) geliştirdiği yedi maddeden oluşan LÜE ölçeği ile ölçülmüştür. Söz konusu ölçek takipçilere yöneltilerek, takipçiler gözündeki etkileşimin kalitesini ölçmeyi hedeflemiştir. Beşli likert formatında hazırlanan ölçekte 3'ün üzerinde elde edilen skorlar kaliteli etkileşime işaret etmektedir. Örnek madde:
"Amirimle olan iş ilişkilerim çok etkindir.". Ölçeğin Türkçe uyarlaması, Özutku ve arkadaşları (2008) tarafından yapılmıştır. $\mathrm{Bu}$ araştırmada, ölçeğin Cronbach alfa güvenilirlik katsayısının .93 olduğu tespit edilmiştir.

\subsection{3. Örgütsel Vatandaşlık Ölçeği}

Takipçilerin sergiledikleri vatandaşlık davranışını ölçmek için Williams ve Anderson (1991) tarafından geliştirilen 14 maddelik ÖVD ölçeği kullanılmıştır. Söz konusu ölçek 7 soruluk ÖVDbirey ve 7 soruluk ÖVD-örgüt olarak iki alt boyuttan oluşmaktadır. Takipçilerin sergiledikleri vatandaşlık davranışı lider tarafindan değerlendirilerek daha doğru sonuçlara ulaşılmaya çalışılmıştır. Ölçeğin tamamının Cronbach $\alpha$ değeri .89 olarak tespit edilmiştir. Alt boyutların güvenilirlik analizi sonuçları ise ÖVD-birey için .85, ÖVD-örgüt için .80 olarak hesaplanmıştır.

\section{3. İșlem}

Hipotez testlerine geçmeden önce araştırmada kullanılan ölçeklerin geçerliliği test edilmiştir. Araştırmada kullanılan ölçeklerin geçerliliği ölçüm modelinin testi üzerinden gerçekleştirilmiştir. Geçerlilik ve güvenilirlik analizlerinden sonra araştırmanın hipotezlerini test etmek için yapısal eşitlik modellemesinde 3 ayrı model oluşturulmuştur. Birinci modelde bağımsız değişkenin bağımlı değişken üzerindeki etkisine bakılmıştır. Aracılık hipotezini test etmek için kurulan 2. ve 3. modelde öncelikle bağımsız değişkenin aracı değişken, aracı değişkenin de bağımlı değişken üzerindeki etkisi test edilmiştir. 3 . Modelde ise bağımsız değişkenin bağımlı değişken üzerindeki etkisine de bakılmıştır. LÜE'nin aracılığının anlamlılığını test etmek için $\chi^{2}$ farklılık testi (Anderson \& Gerbing 1988; Hui, Law \& Chen. 1999) yapılmıştır.

\section{BULGULAR}

Hipotez testlerine geçmeden önce araştırmada kullanılan ölçeklerin geçerliliği test edilmiştir. Araştırmada kullanılan ölçeklerin geçerliliği ölçüm modelinin testi üzerinden gerçekleştirilmiştir. Geçerlilik ve güvenilirlik analizlerinden sonra araştırmanın hipotezlerini test etmek için yapısal eşitlik modellemesinde üç ayrı model oluşturulmuştur. Birinci modelde bağımsız değişkenin bağımlı değişken üzerindeki etkisine bakılmıştır. Aracılık hipotezini test etmek için kurulan 2. ve 3. modelde öncelikle bağımsız değişkenin aracı değişken, aracı değişkenin de bağımlı değişken üzerindeki etkisi test edilmiştir. 3 . 
Tablo 1: Yap1sal Modellerin Karş1laştırması

\begin{tabular}{|c|c|c|c|c|c|c|}
\hline Model ve Y apı & $x^{2}$ & df & $\Delta x^{2}$ & $x^{2 / \mathrm{df}}$ & RMSEA & CFI \\
\hline $\begin{array}{l}\text { Model-1: Dönüşümcü Liderlik } \rightarrow \text { OVD- } \\
\text { birey, OVD-örgüt }\end{array}$ & 467.63 & 187 & - & 2.500 & .080 & .94 \\
\hline Model-2: Dönüşümcü Liderlik $\rightarrow$ Lider & 71822 & 347 & - & 2069 & 068 & 96 \\
\hline Üye etkileşimi $\rightarrow$ OVD-birey, OVD-örgüt & 118.22 & $34 \pi$ & - & 2.003 & .00 & .30 \\
\hline Model-3: Dönüşümcü Liderlik $\rightarrow$ Lider & & & & & & \\
\hline $\begin{array}{l}\text { Üye etkileşimi } \rightarrow \text { OVD-birey, OVD-örgüt; } \\
\text { Dönüşümcü Liderlik } \rightarrow \text { OVD-birey, ÖVD- } \\
\text { örgüt }\end{array}$ & 719.66 & 345 & 1.44 & 2.085 & .068 & .96 \\
\hline
\end{tabular}

modelde ise bağımsız değişkenin bağımlı değişken üzerindeki etkisine de bakılmıştır. LÜE'nin aracılığının anlamlılığını test etmek için $\chi^{2}$ farklılık testi (Anderson \& Gerbing 1988; Hui, Law \& Chen. 1999) yapılmıştır.

Aracılığı test etmek için ikinci modele ilave bir yol eklenerek üçüncü model oluşturulmuştur. Üçüncü modelde ikinci modeldeki ilişkilere ilave olarak bağımsız değişken olan DL'nin bağımlı değişken olan ÖVD-birey ve ÖVD-örgüt üzerindeki etkisine bakılmıştır. İki modelin uyum iyiliği değerlerinin karşılaştırması Tablo 1'de verilmiştir. Analiz neticesinde DL'nin ve LÜE'nin ÖVD-birey üzerindeki etkisi sırasıyla -.09 (p> .05) ve .49 (p< .01 ) olarak tespit edilmiştir. Bağımsız ve aracı değişkenin ÖVD-örgüt üzerindeki etkisi ise sirasiyla $-.07(p>.05)$ ve $.50(p<\quad .01)$ olarak hesaplanmıştır. DL'nin LÜE üzerindeki etkisi de $.82(\mathrm{p}<.01)$ olarak bulunmuştur. Model-3'de ÖVD-birey ve ÖVD-örgüte ait açıklanan varyans ise sırasıyla .17 ve .20 olarak hesaplanmıştır. Aracılık etkisinden söz edilebilmesi için yeni modelde bağımsız değişkenin bağımlı değişken üzerindeki etkisinin anlamsız olması ve iki modelin $\chi^{2}$ farklılık testi, sonuçlarının anlamsız olması gerekmektedir (Anderson \& Gerbing, 1988; Hui vd., 1999). Model -2 ve Model -3'e $\chi^{2}$ farkl1lık testi uygulanmış ve anlamlı bir farklılık tespit edilmemiştir $(\Delta \chi 2=1.44, \mathrm{df}=2, \mathrm{p}=0.486) \cdot \chi^{2}$ farklılık testinin istatiksel olarak anlamlı çıkmaması LÜE'nin, DL, ÖVD-birey ve ÖVD-örgüt ilişkisinde tam aracı etkiye sahip olduğunu göstermektedir. İkinci modelin de uyum iyiliği değerlerinin $\left(\chi^{2}(345\right.$, $\mathrm{N}=235)=719.66 ; \quad \chi^{2} / \mathrm{df}=2.085, \quad \mathrm{RMSEA}=.068$, $\mathrm{CFI}=.96)$ birinci modelle hemen hemen aynı olduğu görülmüştür. Model karşılaştırmalarında, modellerin uyum iyiliği istatistikleri aynı ise, teorik açıdan en tutarlı modelin, araştırma modeli olarak kabul edileceği iddiasından hareketle (Kelloway, 1998) bu çalışmada ikinci model kabul edilmiştir.
Elde edilen bulgular 1şığında H2ave H2bhipotezi kabul edilmiştir. Araştırmada kurulan modellerin yol katsayıları ve açıkladıkları varyanslar Şekil 1'de gösterilmiştir.

Yapısal eşitlik modellemesinde maksimum olasılıklar yöntemiyle yapılan hesaplamalar neticesinde araştırmada kullanılan örneklem için kurulan $\mathrm{H} 1 \mathrm{a}$ ve $\mathrm{H} 1 \mathrm{~b}$ ile $\mathrm{H} 2 \mathrm{a}$ ve $\mathrm{H} 2 \mathrm{~b}$ hipotezlerinin kabul edildiği bulunmuştur.

\section{TARTIŞMA VE SONUÇ}

Bu çalışmada; DL'nin ÖVD'ye etkisi ve bu etkide LÜE'nin aracılık rolünün bulunup bulunmadığ 1 ortaya konulmaya çalışılmıştır. Araştırmanın hipotezleri iki farklı kamu kurumunun Ankara biriminde çalışan 235 kamu çalışanı üzerinde test edilmiştir.

Elde edilen bulgular neticesinde dönüşümcü liderliğin hem ÖVD-birey üzerinde hem de ÖVDörgüt üzerinde olumlu ve anlamlı etkiye sahip olduğuna dair kurulan $\mathrm{H} 1 \mathrm{a}$ ve $\mathrm{H} 1 \mathrm{~b}$ hipotezleri desteklenmiştir. Bu bulgu, DL-ÖVD ilişskisine dair alan yazında var olan bulgularla tutarlılık göstermektedir. Ayrıca LÜE'nin DL-ÖVD ilişkisinde aracı etkiye sahip olduğuna dair ortaya konulan hipotez de beklendiği şekilde desteklenmiştir.

Bu çalışmada elde edilen bulgular neticesinde teorik beklenti ve daha önce yapılan çalışmalarla paralel şekilde DL'nin ÖVD üzerinde olumlu etkiye sahip olduğu ortaya konulmuştur. Öte yandan Casimir ve arkadaşları (2006) yaptıkları çalışmada DL'nin ÖVD üzerindeki etkisinin batı bağlamında anlamlıyken doğu bağlamında anlamlı olmadığını raporlayarak, doğu bağlamında ÖVD'nin DL'den 


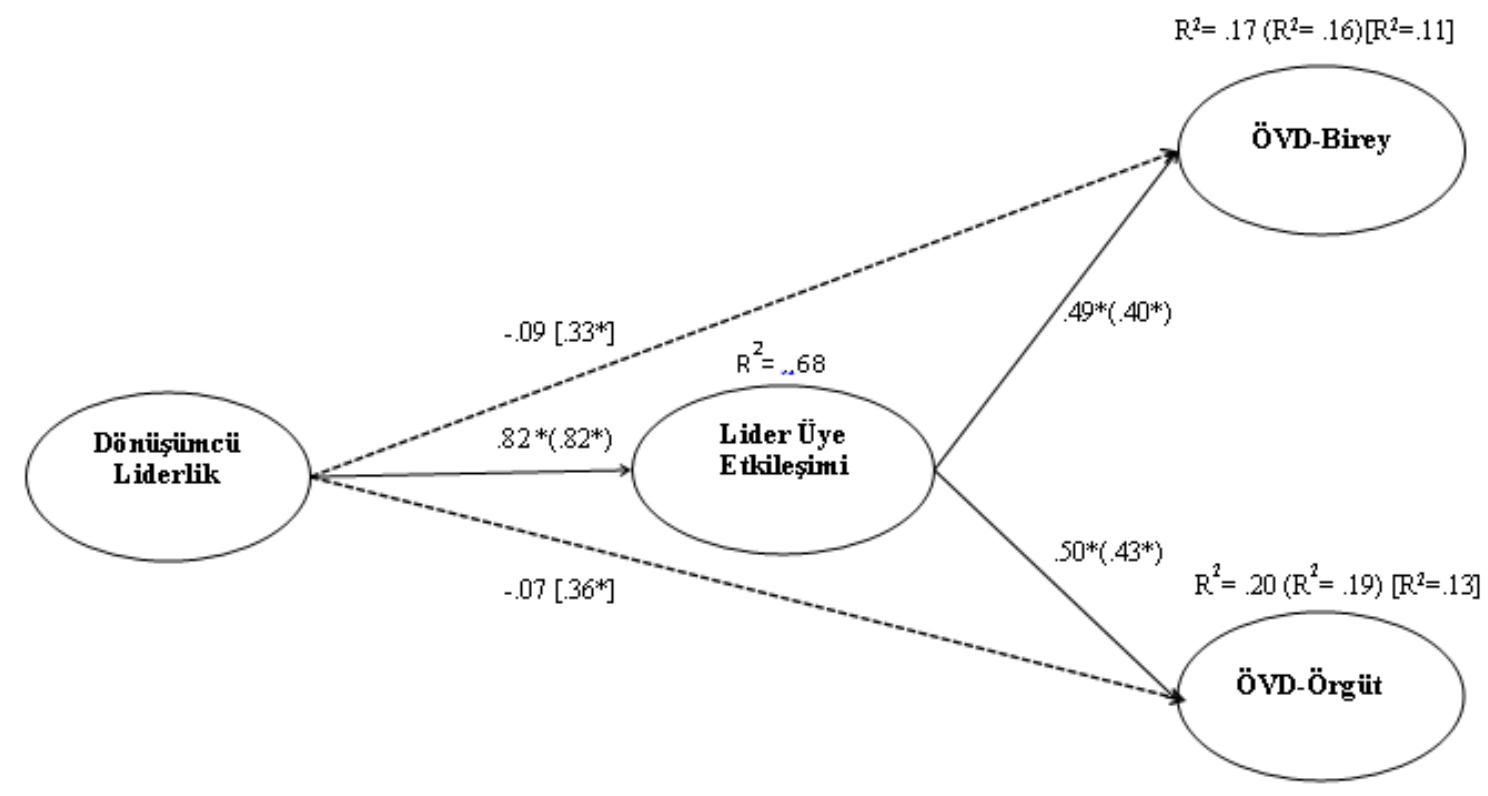

Not: Köşeli [] parantez Mode11'e ait yol katsay1lan ve $\mathrm{R}^{2}$ değerleridir. Parantez() içindekiler Model-2'e ait yol katsay1ları ve $\mathrm{R}^{2}$ de ğerleridir. Parantez dişında yaz1lan değerler Model 3'e aittir. Ke sik çizgi Model 1 deki yolu ve Model-2 de eklenen yol u gösterm ektedir. $* \mathrm{p}<01$

Şekil 1: Yap1sal Model ve Yol Katsay1ları

etkilenmediğini raporlamışlardır. Yazarlar söz konusu bulguyu kültür ile açıklayarak doğu bağlamında vatandaşlık davranışının liderlik tarzından bağımsız bir gereklilik olabileceğini iddia etmişlerdir. $\quad \mathrm{Bu}$ çalışmada Casimir ve arkadaşlarından (2006) farklı olarak Türkiye bağlamında DL'nin ÖVD üzerinde anlamlı etkiye sahip olduğu ortaya konulmuştur. $\mathrm{Bu}$ sonucun altında, Türkiye her ne kadar doğu bağlamında yer alsa da, GLOBE çalışmasında Ortadoğu grubunda yer almasının olduğu düşünülmektedir. Öte yandan Casimir ve arkadaşlarının (2006) yaptığı çalışmada seçtiği örneklem, GLOBE çalışmasında Türkiye'den farklı bir grupta değerlendirilen Çin bağlamında yapılmış olduğu için DL'nin ÖVD üzerinde farklı bir etkiye sahip olması normal bir durum olarak değerlendirilmektedir. Ayrıca elde edilen bulgular alan yazında DL'nin olumlu iş çıktıları üzerinde olumlu etkiye sahip olacağı iddiasının genellenmesine katkıda bulunmuştur (örn., Bass \& Avolio, 1993; Kouzes \& Posner, 2002; Lowe, Kroeck \& Sivasubramaniam, 1996; Podsakoff, MacKenzie, Moorman \& Fetter, 1990). Dönüşümcü liderler takipçilerini etkileyerek ve onlara örnek olarak, örgütsel kazanımları kişisel kazanımların önünde konumlandırmasını sağlayan liderler olarak tanımlanmaktadır (Bass \& Avolio, 1990). DL teorisine uygun olarak bu çalışmada DL'nin ÖVD-örgüt üzerindeki etkisinin, ÖVDbirey üzerindeki etkisinden daha yüksek olduğu tespit edilmiştir. Ayrıca DL tarafından açıklanan varyansın ÖVD-örgüt için .13, ÖVD-birey için .11 olduğu görülmüştür. Kamuda lider pozisyonunda çalışan işgörenler lider ve yönetici oldukları kadar çalışıkları kurumu da temsil etmektedir. Dolayısıyla liderlerin sergileyecekleri DL davranışının, astların kuruma karşı olan tutum ve davranışlarını etkilemesi, sergileyecekleri davranışta kurumu ön plana alması beklenmektedir. Dolayısıyla ÖVD-örgüt'ün DL'den daha çok etkilenmesinde ve az da olsa daha yüksek açıklanan varyansa sahip olmasında, takipçilerin liderlerini kurumun temsilcisi olarak görmesinin ve örgütsel kazanımları daha şahsi kazanımların önünde konumlandırmasından kaynaklı olabileceği düşünülmektedir.

LÜE'nin aracılık rolüne dair elde edilen bulgu takipçilerin sergileyecekleri vatandaşlık davranışını arttırmada lider ve takipçiler arasındaki ilişkinin kalitesinin önemine işaret etmektedir. Bu bulgu, daha önce yapılmış çalışmalar da dikkate alındığında (Deluga, 1992; Dvir, Eden, Avolio \& Shamir, 2002; Howell \& Hall-Merenda, 1999) LÜE'nin önemli bir aracı değişken olduğunu göstermektedir. Elde edilen sonuçlara göre dönüşümcü liderler ile takipçileri arasında öncelikle kaliteli etkileşim tesis edilmektedir. Kaliteli etkileşimin tesis edilmediği durumlarda takipçilerin ekstra rol davranışlarına yönelmesi 
beklenmemektedir. Araştırmada elde edilen bulgularda DL'nin LÜE üzerinde açıkladığ 1 yüksek varyans ve güçlü etkiyle, DL'nin lider ve takipçi arasındaki kaliteli etkileşimin temel kaynağı olduğu görülmektedir. Ancak bu sonucun çıkmasında liderlerin iç grubunda yer alan takipçilerini değerlendirmiş olabileceği ihtimalinden kaynaklı olabileceği düşünülmektedir. Şöyle ki, lider ve takipçilerden ayrı ayrı veri toplanmış olması, liderin tüm takipçilerine ulaşılmasını zorlaştırdığı için liderlerin yoğunluğu dikkate alınarak belirli sayıdaki takipçilerini değerlendirmesi istenmiştir. Bununla birlikte, liderlerin kendilerine yakın olmayan takipçilerini değerlendirmeme eğiliminde olabileceği düşünülmektedir. Dolayısıyla örneklemdeki söz konusu durumlardan dolayı hipotezlerin birbiriyle uyumlu çalışma grupları üzerinde test edilmiş olabilir. Sonuç olarak elde edilen bulgular neticesinde takipçilerin sergileyecekleri vatandaşlık davranışını belirleyicisinin liderleri ile aralarındaki ilişkinin kalitesi olduğu ortaya konulmuştur.

\section{1. Çalışmanın Yazına ve Uygulamaya Katkısı}

$\mathrm{Bu}$ çalışmanın alan yazına üç temel katkısı olmuştur. Birincisi, bu araştırmayla birlikte batı bağlamında ortaya çıkan DL, LÜE ve ÖVD gibi değişkenlerin Türk kültüründe ele alınarak söz konusu değişkenler arasındaki ilişkilere dair geçmişte elde edilen bulguların genellenmesine mütevazı bir katkı sağlanmıştır. Hali hazırda söz konusu değişkenler arasındaki ilişkinin bağlama göre değişebileceğine dair araştırma bulguları dikkate alındığında, bu çalışmada elde edilen bulguların doğu bağlamına dair yapılacak genellemelere katkı sağlayacağı düşünülmektedir.

İkincisi, DL-ÖVD ilişkisi daha önce çalışılmış olmasına rağmen söz konusu ilişkide aracı etkiye sahip olan değişkenlerin daha çok işgören tutumları olduğu görülmektedir. $\mathrm{Bu}$ çalışmada lider ve takipçileri arasındaki etkileşimin kalitesinin aracılık rolünün ortaya konulmasının alan yazına katkı sağlayacağı değerlendirilmektedir. Etkileşim kalitesinin aracı etkisine dair daha önce yapılmış çalışmaların (örn., Deluga, 1992; Dvir vd., 2002; Howell \& Hall-Merenda, 1999) batı bağlamında yapıldığı, ulusal yazında bu konuda bir boşluğun doldurulduğu düşünülmektedir.

Son olarak bu çalışmada liderlerin DL davranışları takipçileri tarafından, takipçilerin sergiledikleri vatandaşlık davranışı ise liderler tarafindan değerlendirilerek veriler çok kaynaktan toplanıştır. $\mathrm{Bu}$ yolla daha önceki çalışmalarda önemli bir kısıt olarak zikredilen ortak yöntem varyansı ve sosyal beğenilirlik etkisini asgariye indirerek (Gürbüz \& Şahin, 2015) değişkenler arasındaki ilişkilerin daha doğru şekilde test edilmesi ve değerlendirilmesi sağlamıştır.

$\mathrm{Bu}$ çalışma uygulamacılar için de önemli katkılar barındırmaktadır. Öncelikle DL davranışı sergileyen liderlerin takipçileri üzerindeki etkisinin ortaya konulmuş olması, takipçilerinin daha çok gönüllü davranışlar sergilemesini isteyen liderlere DL davranışlarının önemini göstermektedir. Takipçilerini motive eden, onları teşvik eden ve onların istek ve ihtiyaçlarına duyarlı liderlerin, takipçileri üzerinde daha etkili olacağı, takipçileri ile arasında yüksek kaliteli etkileşimin tesis edilmesine olanak sağlayacağı ve onların gönüllü davranışlar sergilemesini sağlayacağ düşünülmektedir. Dolayısıyla takipçilerinin işe yönelik olumlu davranışlar içerisinde olmasını isteyen liderlerin DL davranışı sergilemeleri tavsiye edilmektedir.

Bununla birlikte işveren pozisyonunda bulunan veya örgütlerin insan kaynakları eğitim pozisyonlarına yer alanların, lider pozisyonunda istihdam edilen işgörenlere yönelik DL eğitimleri planlamalarının örgütsel çıktılar üzerinde etkili olabileceği düşünülmektedir. Bu sayede dönüşümcü olamayan liderlerin de DL davranışları edinmeleri sağlanarak, örgütteki tüm çalışanlar üzerinde etkiye sahip olunacağı düşünülmektedir.

\section{2. Çalışmanın Kısıtları}

$\mathrm{Bu}$ çalışmanın bazı kısıtları da bulunmaktadır. Araştırmanın örneklemi ilk kısıt olarak değerlendirilmektedir. Zaman ve maliyet gibi etmenler sebebiyle araştırmaya konu örneklemin Ankara'dan ve tek sektörden seçilmiş olması ve belli bir sayıda kalması araştırmanın genellenebilmesi için bir kısıt teşkil etmektedir. Bununla birlikte katılımcıların çoğunluğunun erkeklerden oluşması da değişkenler arası ilişkileri anlamada kısıt oluşturmaktadır. Gelecekte yapılacak çalışmalarda farklı sektörlerden katılımcı cinsiyetinin yakın oranlarda seçilerek yapılmasının daha doğru sonuçlara ulaşma noktasında önemli sonuçların elde edilmesini sağlayacağ düşünülmektedir.

İkincisi, her liderin tüm takipçilerinin araştırmaya dahil edilmemiş olmasının, elde edilen sonuçlar üzerinde etkili olabileceği düşünülmektedir. Şöyle ki, liderlerin sadece iç grubunda yer alan takipçilerini değerlendiriş olabileceği ihtimali, dış grupta yer alan takipçilerin araştırmaya dahil edilmemiş oma ihtimali örneklem hatası olabileceğine işaret etmektedir. Gelecekte yapılacak çalışmalarda her lidere bağlı tüm takipçilerin dahil edilmesi ast sayısı en az üç tutularak bu kısıtın giderileceği düşünülmektedir. 
Son olarak bu çalışmada kesitsel olarak toplanan veri kullanılmıştır. Kesitsel veriden kaynaklı olarak lider ve takipçilerin davranışının yanlış değerlendirilmiş olabileceği düşünülmektedir. Gelecekte yapılacak çalışmalarda boylamsal veri toplanarak bu kısıtın giderilmesi, değişkenler arasındaki ilişkilerin daha doğru değerlendirilmesini sağlayacaktır.

Sonuç olarak bu çalışmada DL'nin ÖVD üzerinde anlamlı bir etkisinin olduğu ve bu ilişkide LÜE'nin aracı etkiye sahip olduğu ortaya konulmuştur.

\section{KAYNAKÇA}

Adams, J.S. (1965). Inequity in social exchange. İçinde L. Berkovitz (Ed.), Advances in experimental social psychology (Cilt.2, ss. 267-299). New York: Academic Press.

Anderson, J.C. \& Gerbing, D.W. (1988). Structural equation modelling in practice: A review and recommended tow-step approach. Psychological Bulletin, 103, 411-423.

Barnard, C.I. (1968). The Functions of the Executive (2.Bask1). Cambridge, Mass: Harvard University Press.

Bass, B.M. (1985). Leadership and performance beyond expectations. New York: Free Press.

Bass, B.M. (1997). Does the transactional transformational paradigm transcend organizational and national boundaries?. American Psychologist, $22,130-142$.

Bass, B.M. \& Avolio B.J. (1990). The implications of transactional and transformational leadership for individual, team, and organizational development. Research in Organizational Change and Development, 4, 231-272.

Bass, B.M. \& Avolio B.J. (1993). Transformational leadership and organizational culture. Public Administration Quarterly, 17(1), 112-121.

Bass, B.M. \& Avolio, B.J. (1995). MLQ multifactor leadership questionnaire. Redwood City, CA: Mind Garden.

Bass, B.M. \& Avolio, B.J. (2003). Multifactor leadership questionnaire feedback report. Redwood City, CA: Mind Garden.

Bass, B.M. \& Riggio, R.E. (2006). Transformational leadership. New Jersey: Lawrence Erlbaum Associates.

Blau, M.P. (1964). Exchange and Power in Social Life. New York: Wiley.

Burns, J.M. (1978). Leadership. New York: Harper \& Row.

Carless, S.A., Wearing, A.J. \& Mann, L. (2000). A short measure of transformational leadership. Journal of Business and Psychology, 14, 389-405.

Casimir, G., Waldman, D.A., Bartram, T. \& Yang, S. (2006). Trust and the relationship between leadership and follower performance: Opening the black box in Australia and China. Journal of Leadership and Organizational Studies, 12, 68-84.

Çetin, Ş., Korkmaz, M. \& Çakmakçı, C. (2012). Dönüşümsel ve etkileşimsel liderlik ile lider-üye 
etkileşiminin öğretmenlerin örgütsel vatandaşlık davranışı üzerindeki etkisi. Kuram ve Uygulamada Egitim Yönetimi Dergisi, 18(1), 7-36.

Deluga, R.J. (1992). The relationship of leader-member exchanges with laissez-faire, transactional, and transformational leadership. İçinde K.E. Clark, M.B. Clark, \& D.R. Campbell (Ed.), Impact of leadership (s.237-247). Greensboro, NC: Center for Creative Leadership.

Dienesch, R.M. \& Liden, R.C. (1986). Leader-member exchange model of leadership: A critique and further development. Academy of Management Review, 11, 618-634.

Dvir, T., Eden, D., Avolio, B.J. \& Shamir, B. (2002). Impact of transformational leadership on follower development and performance: A field experiment. Academy of Management Journal, 45(4), 735-744.

Gerstner, C.R. \& Day, D.V. (1997). Meta analytic review of leader-member exchange theory: Correlates and construct issues. Journal of Applied Psychology, 82(6), 827-844.

Graen, G.B. (1976). Role making processes within complex organizations. İçinde M.D. Dunnette (Ed.), Handbook of industrial and organizational psychology (ss. 1201-1245). Chicago: Rand-McNally.

Graen, G.B., Dansereau, F. \& Minami, T. (1972). Dysfunctional leadership styles. Organizational Behavior and Human Performance, 7, 216-236.

Graen, G.B., Novak M.A. \& Sommerkamp, P. (1982). The effects of leader-member exchange and job design on productivity and job satisfaction: Testing a dual attachment model. Organizational Behavior and Human Performance, 30, 109-131.

Graen, G.B. \& Scandura, T.A. (1987). Toward a psychology of dyadic organizing. İçinde L.L. Cummings \& B.M. Staw (Eds.). Research in organizational behavior (ss. 175-208). Greenwich, CT: JAI Press.

Graen, G.B. \& Uhl-Bien, M. (1995). Relationship-based approach to leadership: Development of leadermember exchange (LMX) theory of leadership over 25 years: Applying a multi-level multi-domain perspective. Leadership Quarterly, 25, 219-247.

Gürbüz, S. (2007). Yöneticilerin örgütsel vatandaşlık davranışlarının iş tatmini ve algıladıkları örgütsel adalet ile ilişkisi. (Yayınlanmamış Doktora Tezi). İstanbul Üniversitesi; İstanbul.

Gürbüz, S. \& Şahin, F. (2015). Sosyal bilimlerde araştırma yöntemleri (Felsefe-Yöntem-Analiz), Ankara: Seçkin.

Harris, K.J., Kacmar, K.M. \& Carlson, D.S. (2006). An examination of temporal variables and relationship quality on promotability ratings. Group \& Organizational Management, 31(6), 677-700.

Hinkin, T.R. \& Tracey, J.B. (1999). The relevance of charisma for transformational leadership in stable organizations. Journal of Organizational Change Management, 12(2), 105-119.

Howell, J.M. \& Hall-Merenda, K.E, (1999). The ties that bind: The impact of leader-member exchange, transformational and transactional leadership, and distance on predicting follower performance. Journal of Applied Psychology, 84, 680-69.

Hui, C., Law, K.S. \& Chen, Z.X. (1999). A structural equation model of the effects of negative affectivity, leader-member exchange, and perceived job mobility on in-role and extra-role performance: A Chinese case. Organizational Behavior and Human Decision Processes, 77, 3-21.

Katz, D. (1964). The motivational basis of organizational behavior. Behavioral Science, 9(2), 131-133.

Keller, R.T. (1992). Transformational leadership and the development of research and development project groups. Journal of Management, 18, 489 - 501.

Kelloway, E.K. (1998). Using LISREL for structural equation modelling: A researcher's guide. Thousand Oaks: Sage.

Kouzes, J.M. \& Posner, B.J. (2002). Leadership challenge (3. Bask1). San Francisco: Jossey-Bass.

Liden, R.C. \& Graen, G.B. (1980). Generalizability of the vertical dyad linkage model of leadership. Academy of Management Journal, 23, 451-465.

Lowe, K.B., Kroeck, K.G. \& Sivasubramaniam, N. (1996). Effectiveness correlates of transformation and transactional leadership: A meta-analytic review of the MLQ literature. Leadership Quarterly, 7, 385425 .

Organ, D.W. (1988). Organizational citizenship behavior: The good soldier syndrome. Lexington: Lexington Books.

Özutku, H., Ağca, V. \& Cevrioğlu, E. (2008). Lider-üye etkileşimi teorisi çerçevesinde, yönetici-ast etkileşimi ile örgütsel bağlllık boyutları ve iş performansı arasındaki ilişki: Ampirik bir inceleme. Atatürk Üniversitesi İktisadi ve İdari Bilimler Fakültesi Dergisi, 22 (2), 193-210.

Piccolo, R.F. \& Colquitt, J.A. (2006). Transformational leadership and job behavior: The mediating role of core job characteristics. Academy of Management Journal, 49, $327-340$.

Podsakoff, P.M., MacKenzie, S.B., Moorman, R.H. \& Fetter, R. (1990). Transformational leader behaviors and their effects on followers' trust in leader, 
satisfaction and organizational citizenship behaviors. Leadership Quarterly, 1, 107-142.

Robbins, S.P. \& Coulter, M. (2007). Management (9. Bask1.). London: Prentice- Hall.

Sargut, A.S. (2010). Kültürler arası farklılaşma ve yönetim. Ankara: İmge Kitabevi Yayınları.

Wang, G., Oh, I., Courtright, S.H. \& Colbert, A.E. (2011). Transformational leadership and performance across criteria and levels: A meta-analytic review of 25 years of research. Group \& Organization Management, 36, 223-270.

Wang, H., Law, K.S., Hackett, R., Wang, D. \& Chen, Z. (2005). Leader-member exchange as a mediator of the relationship between transformational leadership and followers' performance and organizational citizenship behavior. Academy of Management Journal, 48, 420432.

Williams, L.J. \& Anderson, S.E. (1991). Job satisfaction and organizational commitment as predictors of organizational citizenship and in-role behaviors. Journal of Management, 17(3), 601-617.

Yukl, G. (1999). An evaluation of conceptual weaknesses in transformational and charismatic leadership theories. The Leadership Quarterly, 10, 285-305. 